The University of Wisconsin University Extension Division

Department of General Information and Welfare

LEARNING TO EAT POTATOES

In three scenes

Time: About 1577

Place: On a large estate in England

Persons: The lord of the manor, his brother, the gardener, servants, and guests

by Marie Palile Dickoré

Price 5 cents

Copyrighted by the University Extension Division July, 1915 
SB2 $211^{\circ}$
$P 8115$

(C) Cl. A401879

$0.0 \mathrm{~V}$

JUL 241915

no; 
Foreword on

THE WISCONSIN POTATO CROP

\author{
by \\ J. G. Milward \\ Assistant Professor of Horticulture \\ The University of Wisconsin
}

The use of the play ' 'Learning to Eat Potatoes'' should help to arouse in the schools of Wisconsin an interest in the study of one of the most important crops of this state. There are presented below some facts relating to potato growing.

Potatoes are not native to Wisconsin, but originally grew on the cool slopes of Chile and Peru. The greatest development, however, has been far from this native home. Wisconsin is one of the leading states in producing the potato and since 1885 careful selection and breeding have so improved the crop that we now have many varieties, some of which yield as much as four hundred bushels, or approximately twelve tons to the acre. In some European countries where the manufacture of alcohol frompotatoes is an important industry, certain coarse-growing varieties have yielded as high as eight hundred bushels per acre.

The wild potato was small, of a poor quality, and ripened late. From this plant the large, smooth potato which we are accustomed to see, has been developed through long and careful breeding. The term ' 'seed' ' is used here in reference to the small green berries which grow in clusters on the vines. These berries turn a reddish yellow and are the fruits referred to in the play. When the farmer or potato grower uses the term ' 'seed' 'he means the tuber or potato and not the true seed. The tuber is used ordinarily for raising crops because each seed from a berry may produce a plant entirely different from the parent in color, size, shape and quality. Therefore the farmer cannot rely upon the true potato seed but must use the underground tuber for planting purposes.

Wisconsin is especially adapted for raising potatoes because of the suitableness of the soil and climate.

The cultivated potato likes Wisconsin soil and there is no agricultural land in the state where this crop is not grown. Still there are millions of undeveloped acres which have never grown a cultivated crop. Humus is essential, especially where dry summers are common. The vegetable matter retains the moisture and prevents the vines from dying out. Potatoes cannot, however, be grown on the same land year after year without replenishing the soil. The grower usully plows under green clover, stable manure, or other fertilizer to supply the needed plant food (Notrogen, potash, etc.).

The climate of Wisconsin is adopted for the potato growing industry because the first part of the season should be warm and damp for the growth of the green vine, and the latter part, during which the tuber ripens, should be dry and have cool, clear nights. Climatic conditions in Wiscon- 

sin are therefore just right to breed hardiness and vigor in the stock.

So much for the conditions that favor the growing of the potato crop. We must, however, remember that the potato has about as many enemies as any crop grown in the state. Space permits only passing mention of the various pests with which the grower has to contend.

The late blight rot does serious damage during the cold and rainy periods late in August or September. It rots the stems and leaves, and in a few days' time may turn a healthy green field into a rotten mass of smelling vines. The spores or disease germs then enter the ground and begin their mischief on the tubers. The rotten spots on t.2 p tatoes may be very small at harvest time but by the time that they are hauled and stored the rot may spread so rapidly as to ruin whole carloads before they reach the market. When cold, dry weather sets in, the rot as a rule is checked and then dry, hard, rotten spots resembling large blisters show on the potatoes and require the most careful sorting before the stock can be shipped to market. This blight rot is the disease which caused the famine in Ireland in 1845 and the consequent migration into this country. Other diseases of the potato are the common scab, wilt diseases, early blight, black scurf, black leg, leaf roll troubles, etc. but Wisconsin is fortunate because as yet we do not have certain diseases that are so destructive in many of the older potato growing states. Wisconsin is making every possible effort to keep these diseases out and therefore careful inspection is being made and growers are asked not to buy seed potatoes outside of the state, since many of the diseases are spread by seed potatoes.

The harmful insects are also a constant worry to the farmer. The most common insect pests are the potato beetle (bug), the flea beetle, grasshopper and the white grub.

The most advisable control measures against these various troubles are: For the blight, the vines should be sprayed in August and September with a preparation called the Bordeaux Mixture. This is made from Blue Vitriol and common fresh lime according to the following formula:-Blue Vitriol, eight pounds; lime, ten pounds; water, one hundred gallons. The mixture is applied to the vines in a fine spray with machines which cover from four to six rows of plants at a time. The potato beetle may best be killed with Paris Green.

Two standard varieties are grown extensively in Wisconsin, the Rural New Yorker and the Green Mountain. These are both rather late potatoes of a round oblong and flattened shape. The former ha bsluish sprouts and purple blossoms, while the latter has bright green sprouts and white blossoms. It is therefore very easy to separate the two varieties during the summer season when the vines are in bloom, and as it is very important that the fields be kept pure, growers often go over the fields and dig out potatoes of other varieties. Many potato growing communities in Wisconsin have organized an association and have adopted the Green Mountain or the Rural New Yorker variety.

The first car load of potatoes was shipped out of Wisconsin from Waupaca about thirty-four years ago. Last year (1914) over thirty million bushels were raised in the state. The combined shipment from Wisconsin at present would fill a train extending from Lake Superior to Madison, a distance of about 300 miles.

An effort is now under way in Wisconsin to make it easy to place the whole story of potato growing before the young people in the rural schols, for there is something fresh and new in the study of a croplike this which not 

only supplies a problem for study but awakens a deeper interest in the very best things of life which take us close to nature.

All the material needed is available at the very doors of our schools. It will be used adequately as fast as knowledge, leadership, and good teaching are developed.

LEARNING TO EAT POTATOES

\section{Scene I}

Time: Early summer

Place: In the breakfast-room (or in the garden)

Persons: The lord, his brother, several servants

The lord and his brother are seated at the table; several servants are in attendance.

Brother: 'Has't heard nothing lately of thy friend Raleigh?' '

Lord: ' It is near five months since last I heard. I wonder where he is.' '

Brother: ' Sailing in the new world in search of gold, or perhaps a passage to the golden Indies, or some such fool's errand.'

Lord: "Nay, but he makes great conquests over there."'

Brother: ' Great conquests! Ha! Ha! That weed to burn in your mouth or some dusky skinned wildmen. Pooh! T'were better he bided here and worked his estates.' '

Lord: ' 'Aye, but the Queen looks with favor upon his expedition.' '

Brother: 'Favor! Yea, like all women! They court flattery and look upon any one with favor who names a bit of the new country 'Virginia', or who brings a savage princess as a new toy.' '

Lord: "Tut! Tut! Thou must not be so bitter. Raleigh makes a great stir with his new colonies in America.' '

Servant enters, bringing a letter and a package to the lord.

Lord: (breaking the seal) ''Oh, a letter from Raleigh!'' (is busy reading it.)

Brother: "'Where is he now and what new wonder has he found?'

Lord: 'Sailing up the coast of the new land, America.'

Brother: ' What interesting news has he to relate now?'"

Lord: "He tells chiefly of a new plant whose fruit is so very good and which he wishes us to introduce into England.' '

Brother: 'Another of the 'new wonders' to be tried out on us! (Gets up and walks about impatiently) I hardly think it would be worth while to bother with a strange plant." '

Lord: 'Oh, but he says,"' (reading from the letter) 'This plant has great nutritive value; the natives eat it in place of meat. It will be of great value to England and I beg of you, my dear friend, to carefully plant the seeds and prepare the fruit according to the directions I am causing to be enclosed. I entreat your aid in introducing this plant into England. Methinks our beloved Queen will look with favor on him who can do this.' '" 

Brother: 'He speaks of seeds; where are they and like what do they look?' '

Lord: 'They must be in this package. Let us see.'

Brother: (Hands him the package and leisurely moves his chair nearer to watch.)

Lord: (Breaks the seal and opens the package) ' Ah, here they are; now let us have them planted quickly that they may bear fruit

Servant enters. this season."' (Rings the bell-an old cord bell.)

Lord: "Tell the Gardener to come hither."

Servant exit.

Gardener enters.

Gardener: "Yes, Milord?"'

Lord: 'Here are some seeds from America, sent by my friend, Sir Walter Raleigh. He tells in his letter (picks up leter and reads from it) 'This plant has great nutritive value; the natives eat it in place of meat. It will be of great value to England and I beg of you, my dear friend, to carefully plant the seeds and prepare the fruit according to the directions I am causing to be enclosed. I entreat your aid in introducing this plant into England. Methinks our beloved Queen will look with favor on him who can do this.' (To gardener) ' Take thou these seeds and plant them that we may know soon how the fruit tastes.' '

Gardener: 'Yes, Milord, an' if you please, where are the directions?' Lord: ' With the seeds, thou dolt.' '

Gardener: (Examines the package and shakes his head.)

Lord: "Are they not there? (To Brother) Didst thou see them?"' All look for the papers; can not find them.

Brother: (Maliciously) 'Ah ha! now we shall never know how the plant tastes."

Gardener: (Pompously) ''Oh, that does not matter. know how to plant and raise everything. These seeds are but a slight matter to me." '

Lord: (As he and his brother leave.) ' 'Take care thou boastest not too much. These seeds are too precious.'

Exeunt.

Gardener: (Alone) 'Now I've done it again! What do I know of this strange plant. The seeds look as if it would grow like an apple tree. Mayhap t'will be a vine instead of a tree. Yea, surely, for does the pod not look like a dried grape. That's what it will be; a vine growing up high on the trellis an' heavily laden with berries larger than the grape, for are not all things in the new world larger? Now, how shall I plant it? In the sun or in the shade? Plague upon Raleigh and his forgetfulness! No matter, (strutting up and down), I am the gardener; I know how ; there is nothing grows in this earth that I cannot plant, raise, and harvest. (Turning half way to the audience as if to challenge any one who doubted him.) Else, how should I be the gardener?'"

Exit. 

Time: Late summer

Place: In the Banquet Hall of the Lord's manor

Persons: Iord, Brother, Guests, Servants

Servants are seen setting the table for a large banquet.

First servant: "It will be a great occasion today.'

Second servant: ' What is the real reason for this great gathering?'

First servant: "Hast thou not heard? Our lord desires to let his illustrious guests taste the new American fruit.' '

Third servant: 'Hewill be sorely disappointed, for it tastes not good.' '

First servant: "Whence your information?"'

Fourth servant: (Entering) "What's this discussion?"'

Second servant: 'These fellows be saying as how our lord will be sorely disappointed at the new foruit.'"

Fourth servant: 'Aye, that he will. You should have been in the kitchen but a moment ago an' tasted the stuff."

First servant: "How was it?"

Fourth servant: 'Bitter as gall'"

Third servant: ' 'Reminded me much of the new medicine sent recently from America an' said to cure the fever.'"

Second servant:

Fourth servant:

' Mayhap all stuff American has that bitter taste."

' 'Nay, but Raleigh would not send it, an' were it not of some great good.' '

First servant:

'Ah, an' Raleigh it was who sent this plant?"'

Third servant:

Second servant:

' 'Nay, not the plant, the seeds, an' he said the fruit would be of great value to England and how it would please the Queen.' '

Third servant:

First servant:

'An' where does the fellow get all his smartness?'

- 'Did I not bring Milord the letter and the package of seeds? An' did I not hear him read the letter to John, the Gardener?' '

Fourth servant:

'An' how dost know the taste?"

' 'He was in the kitchen, but an hour ago when John brought them in.' '

(Busies himself on the other side of the room.)

Second servant:

Fourth servant:

Second servant:

Fourth servant:

Third servant:

First servant:

Third servant:
"How do they look?"'

(Turned around towards the others) "What, fellows?"

'Why, the new American fruit, of course.'

(Coming towards him) ''Oh, I see. Small, like a yellowish-red hawtree berry. John said they grew on a pretty green bush like a good sized bean bush an' had white, star-like blossoms.' '

' But, ugh, they are bitter!'

'Didst taste them?'"

- Yea, Sallie, the cook, did not know how to prepare them but dared not risk her head by letting it be known, 

so she fried them in butter an" then called us in to taste.'

Fourth servant: 'We were that proud to taste! But, (shuddering) ugh! No one wanted a second tasting. Some one said "put sugar on't', another called for cinnamon. Milord's brother, too, had a taste and pronounced them poisonous."

First servant: "Stand ready! Here they come!"'

Servants take their positions in the dimingroom as the Iord and his brother come in with their guests. They seat themselves around the $\operatorname{tab} I \theta$.

The lord arises and addresses those present:-

- 'Friends, I have assembled you here that I may share with you the honor of being the first to taste the new fruit whose seeds Sir Walter Raleigh sent from America. We planted tho seed and from it came a beautiful bush with pretty leaves and white, star-like blossoms. These turned into berries that are now of a yellowish-red color. Raleigh is anxious for us to take up this fruit and cultivate it for the good of England.'"

First guest: "What name has this new fruit?"'

Brother: ' Raleigh called it 'po-ta-to' (mispronounce the word); spelled p-o-t-a-t-o.'"

Second guest: "Evidently the native name."

Third guest: "How can it be of good to 0ld England?" '

Lord: "Raleigh writes that the natives eat it in place of meat, and we can make use of it in place of bread and meat.' '

Fourth guest: 'I am anxious to try this marvel of a berry that is to supplant our good old oxen and the wheat.' '

Brother: (Rising, glass in hand). ' 'Let us all drink a toast to this new fruit we are to taste today for the first time and for which Raleigh promises so great a future in England. May it prosper in Merrie England!' '

All rise, clink glasses and drink the toast. In the meantime a servant who was sent out by the lord, enters with a covered silver dish which he hands around to each guest. They manifest great curiosity as they help themselves.

First guest:

' What rare opportunity to be the first to try it!'"

(Tastes and makes a wry face; looks questioningly at the others.)

Second guest: (Tasting) "Oh, it is bitter!"

Brother: 'Nay, 'tis not so. Thou art not accustomed yet.'

Third guest:

Fourth guest:

Fifth guest:

Brother:

' There is not enough of sugar on 't.' '

' It savors too much of cinnamon."

" I do not Iike it." '

' Nay, nay, be not hasty in thy judgment. 'Tis new. Thou hast not learned to like it. Try it again.'

(Passes the dish over to him.)

Sixth guest: "It tastes like the new medicine from the new land." 

Brother: (Handing him the silver dish.) 'Take more; thou must learn to like it. Didst like the olive at first taste?' '

Seventh guest: 'I am sore afraid this fruit is not suitable to England's climate.' '

Brother: (Laughing aside) ' Nay, but thou art sore afraid. Try some more. Thou wilt like it better as thou cultivatest the taste.' '

First guest: (To second guest.) "'I do not feel well; methinks I am poisoned."' (Rises and says to the lord.) "I find a fit of ague coming overme. I must get home and to bed. Thou wilt excuse me?' '

Second guest: 'Pray let me accompany thee home safely. (To the lord) I'll see him to his home and let thee know." '

Both exeunt.

Third guest: 'I just remember, my wife's mother will come with today's coach. I must not fail to meet her. Thou wilt be so kind as to excuse me?'"

Exit.

Lord: ' Why, but, (bewildered) what means this sudden leavetaking?' '

Brother: (Patronizingly, as all guests come up, take leave and go out.) ''Do not fear, dear brother, they will come around to thine and Raleigh's love of this new fruit. Mayhap if you should plant the seed in sugar or molasses t'will become more palatable.'

Lord sends for the gardener who comes in with a frightened look on his face.

Lord: (Angrily.) ' What shame is this thou hast brought on my head? What didst thou do to spoil Sir Raleigh's new fruit? Thou numskull! Thou dolt! Thou worse than dunce! Tear out the plant! Destroyit, burn it, anything to get it out of my sight, and get thee out too. I'Il have none of thee. I'll have some one who knows how to grow these precious plants from America. Out of my sight! Thou art no gardener!'

The lord and his brother exeunt.

Gardener: (Left alone, is very much dejected.) ' What? I no gardener? Now see rrhat has come of my boasting. An' he blames it all on me. Why not the cook? But then, did I not plant the seed expecting it to be a vine, an' it came up a bush? Mayhap I gave it not enough of sun. Alas, that I boasted of my great knowledge. A wiser man had held his tongue. An' now for the tearing out of the plant that has caused my downfall. Yes, I'll burn it, and I'll do it so well that Milord will take me on again. (Exit shouting.) What! Ho! A brand! Fire! Fire! Fire!' 

The real potato

Time: Afternoon of the same day

Place: In the garden

Persons: The lord, the gardener, servants

Servants are in the garden performing different duties. First and fourth servants and the cook's boy enter, meet and talk. As they talk the fif th servant enters, evidently from the city, for he carries packages. As they all talk the other servants crowd around, joining in with expressions of interest in the tasting of the potato, the dinner scene, the wrath of the lord, the sending away of John.

First servant: ' Faith! but Milord was sore angry!

Fifth servant enters.

Boy: ' 'I was that glad that I was not in John's boots.' '

Fourth servant: (Seeing the fifth servant.) ' 'What! Ho! Come hither. Thou didst miss the row.' '

Fifth servant: (Coming up and depositing his parcels on the ground.) ' 'How's that?'

Boy: ''John, the gardener's been dismissed.'

Fifth servant: ' 'What? An' when did that happen?' '

First servant: 'At the banquet Milord gave today to introduce the American fruit.' '

Fifth servant: ' An' why should John be sent away?''

Fourth servant: "'The new fruit was a grand failure. The guests did not like it at all.' '

First servant:

Fifth servant:

Fourth servant:

First servant:

Fifth servant:

Boy:

Fifth servant:

"They all left before the meal was over."

' 'An' why should they leave?'"

' The fruit was that bitter and ill-tasting they would not stay."'

' ' I guess they thought they were poisoned.' '

' 'An' was't so bad?' '

' 'Ugh! thou shouldst have tasted of it. The cook put sugar and cinnamon on to make it taste better.' '

' But what of John; what did the new fruit have to do with his dismissal?'"

Fourth servant:

' Milord held him responsible for not knowing how to plant the seeds and raise the plant.' '

Fifth servant:

First servant:

Fifth servant:

' Oh, that'sit, is it?'"

' Thou shouldst have been here instead of in town.' '

' Aye, that I wish. 'T'would have been sport to see them try to eat of it.' '

Boy: 'Here comes Milord.' (Runs away as fast as he can.)

First servant: ' 'Let us hasten out of the way that he can not vent his spleen on us.' ' 

All the servants hasten away in opposite directions from the entrance of the lord. The lord walks through the garden; comes upon a fire.

Lord: 'Gardener! Here! Come hither!'"

Gardener: (Running up to him.) ''Yes, Milord.' '

Lord: (Angry at seeing him still in the garden.) ' What, thou art still here? How comes this fire?'

Gardener: 'You bade me tear out the new American plants an' destroy them, an' so I have pulled them all up an' am destroying them as fast as fire will burn.' '

Lord: ' Well, all right. Thou has been industrious. Yes, Yes, thou art mending thy ways. I see. What are yon black balls on the edge of the fire?"'

Gardener: ' They hung in great numbers on the roots of the plants an' I have dug them all up to burn them with the plants, for you said I was to destroy them.' '

Lord: "Yes, yes. Get me one of those balls.'

Gardener, eager to please, stoops to get one; picks it up; too hot, tries to hold it first in one hand, then in the other; blows his fingers; dances from one foot to the other; finally the potato falls out of his hands and rolls before the feet of the lord who steps on it. As the potato bursts they both bend over it.

Lord: "Ha! that smells savory.'"

Gardener: (Picksitup, hands a part to the lord, smells at the other part.)

Lord: (Smells and tastes.) 'That tastes good."'

Gardener: "It truly does taste good." (Eats all of his part of the potato and with a stick tries to find more in the fire.) 'An' salt would make it better.'

Lord: (As he eats his part meditatively.) 'And butter!' (Suddenly.) ' Aha! now I know what Raleigh meant by fruit. Now I know what he meant by nutritive value and substitute for bread and meat. I'll go to the house and send for all my friends again to let them taste of this savory fruit. Pick thou all the balls up to take to the cook and tell thou the cook how to prepare them. (Turns to leave but remembers the gardener.) Thou mayest stay in my service.' '

Gardener: (Bowing.) ' Many thanks, Milord.'' The lord exit. Gardener: (Seems to expand with returned self-confidence.) ' Ha! That was a good turn this fruit did me now. I always knew I was a gardener. Who planted the American seed? I did. Who so carefully raised the plants an' tended them? I did. Who was't found the balls and built the fire and roasted them to such a savory turn? 'Twas I alone, the gardener! (Indicating the direction in which the lord went.) He realized in good time that he could not get along without me. But for me, Sir Walter Raleigh's new fruit would have perished in English soil. The Queen (Strutting off the stage.) should look upon me with favor. I am The Gardener!'

Exit. 


\section{LIBRARY OF CONGRESS}

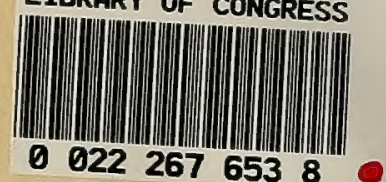

